\title{
BETWEEN THE CRITICISM OF HADÎTS AND HADÎTS PROBATIVENESS
}

\author{
Idri \\ (A Lecturer and Chief of State Islamic Higher Education (STAIN) \\ Pamekasan, JI. Raya Panglegur Km. 04 Pamekasan, email: \\ idri_idr@yahoo.co.id)
}

\begin{abstract}
A bstract:
Setiap Muslim percaya bahwa al-Qur'ân secara wurûd bersifat qath'î, karena ia dikumpulkan dan ditulis pada masa Nabi serta ditransmisikan secara mutawâtir. Namun tidak demikian dengan H adîts. Ia tidak semuanya ditulis pada masa Nabi. Karenanya, para ulamâ' berupaya mengkaji $\underline{H}$ adîts berikut rantai transmisinya untuk menentukan validitas (ke-shahîh-an) sebuah $\mathrm{H}$ adîts melalui kritik transmisi Hadîts. Artikel ini akan menyoroti persoalan tersebut, sehingga akan memberikan pemahaman tentang makna dan syaratsyarat kritik Hadîts serta hubungan antara kritik Hadîts dengan validitas dan pengujiannya. Validitas Hadîts tidak hanya bergantung pada Hadîts itu sendiri, tetapi ditentukan melalui investigasi historis dan pendekatan metodologis. Dalam kaitan ini, kemampuan personal dan kualitas intelektual para perawi Hadîts memiliki peran signifikan dalam menentukan apakah sebuah Hadîts itu diterima atau tidak. Untuk itu, ktirik Hadîts tidak hanya bertujuan untuk menilai dan mengetahui validitas sebuah Hadîts dan profesionalitas perawinya, tetapi juga untuk mengakomodasi kebergunaannya sebagai sumber hukum Islam kedua.
\end{abstract}

\section{Keywords:}

$\underline{H}$ adîts, criticism, probativeness, and validity

\section{Preface}

It is said in the Qur'an that Allâh preserved and guarded it from any corruptions. In surat 15: 9, Allâh said: We have, without doubt, sent down the message and we will assuredly guard it (from corruption). The promise made by Allâh in this verse is obviously fulfilled in the undisputed purity of the Qur'anic text throughout the fourteen centuries since its revelation. Every Muslim believes that the Qur'an consists of the word of God revealed in A rabic by God to the Prophet 
Muhammad -- Allâh bless and greet him -- over a twenty-two year period. He received the first revelation in the year $610 \mathrm{CE}$ while engaging in a contemplative retreat in the the cave of Hira located on the Mountain of Light (Jabal al-N ûr), which is in the outskirts of Mecca. Eventhough in accordance with its content and substance, the Qur'an is distinct from hadîts, which are the sayings of Muhammad and it is agreed that Muhammad -- Allâh bless and greet him -- clearly distinguished between his own utterances (hadîts) and God's words (the Qur'an), ${ }^{1}$ so the Qur'an is always claimed as al-wahy al-matlu, which is the recited revelation because its text and essences came from Allâh altogether ${ }^{2}$ and the hadîts is claimed as al-wahy ghayr almatlu, that is the unricited revelation because its essences came from Allâh and the text from the Prophet Muhammad, it is believed among muslims that both of them are the main sources of Islamic theaching.

The divine promise mentioned in the verse above also includes, by necessity, the hadîts of the Prophet Muhammad, because the hadîts is the practical example of the implementation of the Qur'anic guidance, the wisdom taught to the Prophet along with the scripture, and neither the Qur'an nor the hadîts can be understood correctly without the other. On the other hand, Muslims and most Western scholars of Islam believe that the Arabic Qur'an that exists today contains substantially the same Arabic that was transmitted by the Prophet Muhammad. The text of the Qur'an was written, memorized, and collected since it was at the time of the Prophet. Therefore, every Muslim believes that all contents of the Qur'an are valid because they were transmitted in the way of mutawâtir. ${ }^{3}$

On the contrary, it is not every hadîts was written during the time of Prophet Muhammad. It is a historical fact, accepted by

IFazlur Rahman, "The Living Sunnah and al-Sunnah wa al-Jama'ah," in P.K. Hoya (ed.), H adîts and Sunnah: Ideals and R ealities (Kuala Lumpur: Islamic Boook Trust, 1996), hlm. 150

2 Since M uslims believe that words themselves are those revealed by God, the act of reciting or reading the Qur'an is believed to be a means of receiving blessings from God. Hence it is not uncommon that Muslims will learn how to read Arabic and the Qur'an without understanding it. Also, even those who cannot read the Arabic letters of the Qur'an believe that they can nevertheless benefit from hearing the evocative quality and blessedness of the original Arabic.

3 M utaw âtir (consecutive) is a hadîts which is reported by such a large number of people that they cannot be expected to agree upon a lie, all of them together. 
Muslims and non-Muslims alike, that the writing of the hadits done by Muslim is not for all. Just a view hadîts that had substantially written. The Prophet sometime ordered Muslim (namely his companions/ alshahâbah) 4 to write hadîts and some of them did it to get the blessings of him. In other words, some hadîts were written down during the life of the Prophet, while others were passed on orally and collected later. Scholars study the Prophetic Traditions (hadîts) and their chains of oral transmission to determine which are valid or authoritative. No hadîts is held true or cited as a proof unless it can be authentically attributed to the Prophet.

This is, may be, the way Allâh to preserve the hadîts by enabling the Companions and those after them to memorize, write down and pass on the statements of the Prophet, and the descriptions of his way, as well as to continue the blessings of practicing the hadîts. ${ }^{5}$ But, in other time the Prophet also prohibited Muslims to write the hadîts. Many reasons supposed to be the hindrance of writing, such as they were fear if the hadîts writing texts can not be separated from the Qur'an. The result of this is the vast majority of Muslim scholars rest assured that not every hadîts are authentic from the Prophet, some of them are fabricated especially since Alî Ibn A bî Thâlib period. ${ }^{6}$

To face such condition, as purity of knowledge of the hadits became threatened, the Muslim scholars with exceptional memory skills and analytical expertise, traveled tirelessly to collect thousands of narrations and distinguish the true words of prophetic wisdom from those corrupted by weak memories, from forgeries by unscrupulous liars, and from the statements of the large number of U lama (scholars), the companions and those who followed their way.

\footnotetext{
4 The Muslims who lived at the time of the Prophet.

5The actual collection of hadîts, became a systematic science of hadits about two centuries after the death of the Prophet Muhammad. Until then, there were stories on Prophet Muhammad's and his followers' lives called shirah. To what extent thesewere used as guidance for Muslims is somewhat difficult to ascertain, but the collecting and systemizing of these stories two centuries later would not have been possible were it not for a system explaining the use of siras in the everyday life of Muslims. 6See Muhammad 'Ajjâj al-Khatib, al-Sunnah qabl al-Tadwîn (Beirut: Dâr al-Fikr, 1971), hlm. 128, Mustafa al-Siba'i, al-Sunnah wa M akanatuha fi al-Tashri' al-Islami (Beirut: alMaktab al-Islami, 1985), 75, Subhi al-Shalih, 'U lûm al-H adîth wa M ustalahuh (Beirût: Dâr al-'Ilm li al-Malayin, 1988), hlm. 266, al so Muhammad Muhammad A bu Zahw, al-H adîth wa al-M uhaddithûn (Beirût: Dâr al-Kutub al-'Arabi, 1984), hlm. 114.
} 
All of this was achieved through precise attention to the words narrated, and detailed familiarity with the biographies of the thousands of reporters (narrators) of hadits. What they were doing is in acoordance with the keeping of it's originality through the implementation of critique of hadîts transmission.

The methodology of the expert scholars of hadîts in assessing the narrations and sorting out the genuine from the mistaken and fabricated, for the subject matter of the science of hadîts. Therefore, in this article a brief explanation is given of the significance of hadîts criticism to its validity and probativeness. Through the explanation, it is hoped that we can understand the meaning and conditions of hadîts criticism as well as the significance of principles of criticism, validity, and hadîts probativeness.

\section{The M eaning and Conditions of Hadîts Criticism}

A hadîts is a saying of Muhammad or a report about something he did. $\underline{H}$ adîts also means a report about a saying (qawl), doing (fi'l), or agreement (taqrir) of the Prophet.7 In other word, the term hadîts refers to reports about the statements or actions of the prophet or about his tacit approval of something said or done in his presence. $\underline{H}$ adîts might be a report of what the Prophet said, did, or what he approved or disapproved of. M.M. Azami formally defines hadîts as follows: "According to M uhaddithun [scholars of hadîts] it stands for what was transmitted on the authority of the Prophet, his deeds, sayings, tacit approval, or description of his features, meaning his physical appearance. However, physical appearance of the Prophet is not included in the definition used by the jurists. Thus hadîts literature means the literature which consists of the narrations of the life of the Prophet and the things approved by him. However, the term was used sometimes in much broader sense to cover the narrations about the Companions [of the Prophet] and Successors [to the Companions] as well."8

The hadîts regulates the life of a Muslim. The Qur'an contains scant details of many of the duties of the Muslim, and the hadîts filled

7 Shalih, 'U lûm al- $\underline{H}$ adîts, ibid., hlm. 66

8 M. M. Azami, "Studies in Hadîts Methodology and Literature." Quoted in "Sunnah and H adîts," at: http:/ / www.uscedu/ dept/ MSA. 
in the gap by providing the details. For example, the shalat is described in detail in the hadîts but not in the Qur'an. Unfortunately, over time, during the first few centuries of Islam, it became obvious that many so-called hadîts were in fact spurious sayings that had been fabricated for various motives, at best to encourage believers to act righteously and at worse to corrupt believers' understanding of Islam and to lead them astray. ${ }^{9}$ Since Islamic legal scholars ${ }^{10}$ were utilizing hadîts as an adjunct to the Qur'an in their development of the Islamic legal system, it became critically important to have reliable collections of hadîts. While the early collections of hadîts often contained hadîts that were of questionable origin, gradually collections of authenticated hadîts called shahîh were compiled.

Such collections were made possible by the development of the science of hadîts criticism, a science at the basis of which was a critical analysis of the chain of (oral) transmission (al-isnad) of the hadîts going all the way back to Muhammad. The two most highly respected collections of hadîts are the authenticated collections the Shahîh Bukhari and Shahîh Muslim.11 To know the accuracy and validity of hadîts, it is needed to understand about the science of hadîts criticism which literally means 'The Science of $\underline{H}$ adîts Criticique'. The word criticism derived from criticize which means: [1] to make judgments about the good and bad points of, and [2] to judge with disapproval. Therefore, a critic (al-naqid) is: [1] a person who gives judgments about the good and bad qualities of something, and [2] a person who dislikes and expresses strong disapproval of something or someone.12 It is also a peson with a disparaged character, such as due to his telling lies, excessive mistakes, opposition to the narration of more

9Musthafâ al-Siba'i, al-Sunnah, 79, Shalâh al-Dîn ibn Ahmad al-A dabi, M anhaj N aqd al$M$ atn 'Ind 'U lamâ' al- $\underline{H}$ adîts al-N abawi (Beirut: Dâr al-Aflaq al-Jadîdah, 1983), hlm. 30; al-Khatib, al-Sunnah, hlm. 189, and John Burton, An Introduction to the Hadîts (Edinburgh: Edinburgh University Press, 1985), hlm. 108

10There are four Islamic legal scholars who were the founding fathers of madzhab, namely A bû Hanîfah, Mâlik ibn Anas, al-Syâfi'î, and A hmad ibn Hanbal. They were all utilizing hadîts as an adjunct to the Qur'an in their development of the Islamic legal system even though in different style and methodological concept.

11 Shahîh literally means correct, true, valid, or sound.

12Longman, D ictionary of Contemporary English (Oxford: Oxford University Press, 1988), hIm. 243 
reliable sources, involvement in innovation, or ambiguity surrounding his person.

In Arabic language, criticism literally means al-naqd such as 'naqada al-kalam wa naqada al-shi' $r$ '. ${ }^{13}$ In A rabic, hadîts criticism is kown as naqd al-hadîs. The meaning of naqd or naqada is to research, to analize, to check, and to differenciate. ${ }^{14}$ Depends on this four meanings, hadîts criticism indicates quality of hadîts research, critical analysis of the chain of transmission (al-isnad) and material aspect (almatn) of the hadîts, and differentiation between authentic (shahîh),15 weak (da'if) ${ }^{16}$ and even false hadîts (mawdu'). ${ }^{17}$

The purpose of hadits criticism is not to reject the authenticity of hadîts and its role in the Muslem society. This is different from the doctrine of Inkar al-Sunnah group who have rejected hadits or sunnah as a source of Islamic teachings after the Qur'an. Therefore, the criticism can not reject the authentic hadîts to be unauthentic, as what had been done by some of Western scholars (Orientalists) such as Goldziher, Joseph Schacht, and others. The probable hadîts can be accommodated with the authentic one and the Qur'an by many devices: abrogation, particularization, exception, restriction, interpretation, etc. In this case, the critique of the hadîts or hadîts criticism is one thing and its rejection is something else. Ancient and

13E.W. Lane, A rabic English Lexicon, vol. 8 (Edinburgh, 1967), hlm. 2836

${ }^{14} \mathrm{H}$ ans Wehr, A Dictionary of M odern W ritten A rabic (London: George Allen \& Unwin Ltd., 1970), hlm. 990

15Shahîh or the authentic hadîts is a hadîts which has connection of the chain of transmission (ittishal al-sanad), each of its reporter should be trustworthy in his religion ('adil), he should be known to be truthful in his narrating and he understands what he narrates (dlabit), the sanad and/ or the matn free from 'illat or syadh.

${ }^{16 D}$ la'if or weak hadits is a hadîts which fails to reach the status of shahîh or hasan. Usually, the weakness is: [a] one of discontinuity in the isnad, in which case the haditts could be - according to the nature of the discontinuity - munqati (broken), mu' allaq (hanging), mu'dal (perplexing), or mursal (hurried), or [b] one of the reporters having a disparaged character, such as due to his telling lies, excessive mistakes, opposition to the narration of more reliable sources, involvement in innovation, or ambiguity surrounding his person.

$17 \mathrm{M}$ awdlu' or fabricated/forged hadîts is a hadîts which text goes against the established norms of the Prophet's sayings, or its reporters include a liar. Fabricated hadîts are also recognized by external evidence related to a discrepancy found in the dates or times of a particular incident. 
modern scholars criticized the hadîts in order to purify it from the unauthentic narratives. No one, Shi'ite or Sunnite, rejected it as a second source of law.

The critique to narrators of hadîts needs special treatment by which they can assume the rules that should be noticed to do. The ancient and modern hadîts scholars (al-mutaqqaddimun and almutaakhirun) had sufficiently given conditions which have to be fulfilled by narrator critics of hadîts (al-jârih wa al-mu'addil). Only ones who have fulfilled such connditions can his saying be recognized. Generally, the conditions could be classified into two groups. Firstly, the conditions in accordance with personal attitude, namely: [1] Should be fair in the term of hadits studies or the integrity of narrators ('adala al-ruwâ); [2] Having no fanatic attitude to the belief acknowledged; [3] Having no prejudice and dislike performance to the different narrators in belief and school of law or theology; [4] Being honest; [5] Being afraid to God (taqwa); and [6] Keeping self from any unsuggested things (wara'). Secondly, the conditions in accordance with the fulfillment of knowledge, namely the width and depth of understanding in Islamic teachings, A rabic language, hadîts and the science of hadîts, the man whom he criticizes, and the customs ('urf) as well as the goodness and badness causes of the narrator. ${ }^{18}$

Besides the subjective conditions mentioned above, there are some critical norms which have to be followed by the critics of narrators (nuqad al-ruwah). Those norms had been determined by hadîts scholars in order to keep the objectivity of judgment and to keep hounorable etics in hadîts critique. Clearly speaking, the critics of narrators who had fulfilled subjective conditions also should fulfill the objective norms to make their judgment accurate and valid. Those norms are:

[1] In criticizing and scrutinizing the narrators, the critics (alnuqad) not only express the negative and bad characters of

\footnotetext{
18See: A h hmad ibn 'Alî ibn Hajar al-'A sqlani, N uzhah al-N azhâr Syarh Nukhbah al-Fikâr (Semarang: Maktabah al-Munawwar, 1986), hlm. 67-68, 'Alî ibn Sulthân al-Harawi al-Qari, Syarh N ukhbah al-Fikâr (Beirut: Dâr al-Kutub al-'Ilmiyah, 1978), hlm. 236-238, Nur al-Dîn 'Itr, M anhaj al-N aqd fí 'U lûm al-H adîth (Damascus: Dâr al-Fikr, 1979), hlm. 93-94, Muhammad 'Ajjâj al-Khatib, U shûl al-H adîth 'U lûmuh wa M ustalahuh, (Beirut: Dâr al-Fikr, 1989), hlm. 267, and Muhammad 'A bd al-Hayy al-Laknawi, al-R af'u wa alT akmil fî al-Jarh wa al-Ta'dîl (Halb: Maktab al-Mathbû'ah al-Islâmiyah, 1985), hlm. 67.
} 
them (al-jarh) but also the positive and honourable ones (alta'dil). This means that to make 'equilibrium' or al-wust of judgments, one should consider whether his narration can be accepted or not.

[2] The explanation of positive and honourable characters (alta' dil) occupied by hadîts critics must not be detail and specific, one by one but it can be in general and in broad spectrum. The words of the critics can be accepted with general utterances such as siqa (trusworthy) to denote the typeset of the' adalah of narrators dealing with their personal capasity and their dabt aheading of intelectual quality. The term tsiqah indicates specific terms such as being muslim, having devotion (taqwa), keeping muru'ah, strengthening religious doctrine implementation, being accurate, et cetera.

[3] In exposing the negative characters of narrators, an excessive treatment is not allowed. The expression used should also be clear in accordance with the aspects criticized whether personal capacity, intellectual quality, or both of them. 19

On the light of ethical code above, some hadîts scholars assumed that the critique text should imply moral norms. Al-Sakhawi (w. 902 H./ 1496 M.), quoted by al-Laknawi (d. 1304 H./ 1886 M.), said that if it is possible the negative critique (al-jarh) must be undertaken by using the most polite words. Al-Syâfi'î (d. 206 H./ 820 M.) also suggested that the critics of narrators should widen and improve their utterance and not said 'a lier' instead of 'his hadîts is okey'.20 Even, to the narrator who has been examined as a fabricator so his/ her hadîts supposed as false, al-Bukhari said that he/ she is just a munkar hadîts. ${ }^{21}$ But, it does not mean that in certain condition, the fabricated hadîts will become shahîh (valid) if an ulama says that it is authentic.

19 See: N ûr al-Dîn 'Itr, M anhâj, hlm. 95-96, al-Khatib, Ibid, hlm. 266-268, A bû 'A mr 'Utsmân ibn 'A bd al-Rahmân ibn al-Shalâh, 'U lûm al- $\underline{H}$ adîts (al-Madînah alMunawwarah: al-Maktabah al-'Ilmiyah, 1972), hlm. 96-98, Tâj al-Dîn ‘A bd al-Wahhab ibn 'A lî ibn al-Subki, al-Q â'idah fi al-Jarh wa al-Ta'dîl wa al-Q â'idah fî al-M ua'arrikhîn (alQâhirah: Maktab al-Mathba'ah al-Islamiyah, 1984), hlm. 23, al-'Asqalani, Ibid, hlm. 68.

20Muhammad 'A bd al-Hayy al-Laknawi, al-A jwibah al-Fâdilah li al-A s-ilah al-'A sharah al-K âmilah (Beirut: Maktabah al-Matbu'at al-Islamiyah, 1993), hlm 57

${ }^{21}$ 'U mar ibn Hasan 'Utsmân Fallatah, al-W ad'u fî al-H adîth, vol. II (Beirut: Muassasah Manâhil al-'Irfan, 1981/ 1401), hlm. 214 
Actually, the authenticity of hadîts does not depend on the argumentation of hadîts scholars but depends on the data acquired from the past. The Scholars only had duty to analyze and give comment to the data. Therefore, the quality of a hadîts will be as it be unless there are some data indicates the opposite term.

\section{The Principles of Criticism}

When early Muslim scholars collected the hadîts, they used two methods. The first method weighed authenticity by testing the chain of the story's transmitters (al-isnad). Scholars would analyze how far back in time it was possible to trace the transmission, and whether the transmitters were reported to be honest people, etc. The other method testing the text of hadîts (al-matn) either by checking its contents or its text. The more a content or text indicates validity, the more reliable they were considered to be. The accuracy of Muhammad's sayings was confirmed by his contemporaries -- generally his companions; i.e. his immediate followers. Some Muslims regard all of the the hadîts as being valid, but the other not. The last needs hadîts criticism.

The hadîts criticism can be undertaken internally, according to the same rules put forward by ancient scholars applying the rules of the hadits to scrutinize the narratives of its contents. For example, the condition of the multilateral report, mutawâtir, is sufficient to guarantee the concordance of the report with reason and sensory evidence, called by the logic, history and science. The hadîts scholars could have readjusted the old rules of criticism making them more rigorous rather than rejecting the hadits. No critics were more scrupulous than the ancient scholars. What they offered in criticism is much less than what the ancient scholars created in laying the ground for modern criticism.

If one tries to apply the rules of the hadits whether to scrutinize the narrative or to guarantee the report with reason and sensory evidence, he will find that the science of hadîts has many aspects and rules which can be used as methodological approach to differ between the authentic and the forged. We can look for and then analyze the chain of narrators (al-sanad) as well as the contains of hadîts (al-matn) through research to the 'historical actors' who had involved in transforming hadîts to their next generations. We can also analyze its contents with reason and sensory evidence relating to science, logic, 
the law of nature, environmental cases, and of course, moreover, the utterances of the Qur'an, the hadits it self as well as the consensus of ulamâ'.

The hadîts scholars had been developed the basic principles of hadîts critique (dirayah al-hadîts) which can be classified into two categories: [1] the critique relating to the isnad system, and [2] the critique concerning with the matn (text) of hadîts. The most prominent objects implemented in isnad system concerning with hadîts literatures is biographical problems and the evaluation to the hadîts narrators (asmâ' al-rijâl) that is: [1] time chronology, [2] biography, [3] evaluation to the quality and capacity of hadîts narrators, [4] their rank as narrators (al-thabaqat), [5] the aspects of their life which could support to identify their identity, truthfulness, and validity, [6] the evidences of their narrations as well as the commentary of hadits critics, ${ }^{22}$ and [7] the method in transmitting and receiving hadîts (tahammul wa ada' al-hadîts).

The evaluation of isnad system, its original, and its implementation to hadîts, the origin and development of biographic literatures, the qualification of its narrators et cetera, become the object of hadîts studies through sanad perspective. The hadîts scholars tend to recognize the sanad as external parts as well as the proof of the authenticity of hadîts. As a chain of narrators who connect to the text of hadîts, ${ }^{23}$ or the way to matan, ${ }^{24}$ sanad has important role in providing the validity and authenticity of matn because by it the hadîts historically can be provided as long as the research and evaluation done.

In general, the principles of sanad criticism can be explained as follows: [1] Every hadîts should be able to be connected from the first to the end of sanad clearly identity, unquestionable character, the best

\footnotetext{
22See Abu Hatim al-Razi, Kitâb al-Jarh wa al-Ta'dîl (Hyiderabad: Majlis Dâirah alMa'ârif, 1952), al-Dhahabi, Tadhkirah al-Huffâzh, vol. I (Heiderabad: The Dâirat alMa'ârif el-Othmaniya, 1955), the same author, M izân al-'I'tidâl fî N aqd al-Rijâl, vol. I (Beirut: Dâr al-Kutub al-'Ilmiyyah, 1995 M.), Ahmad bin Hajar al-'A sqalani, Tahdhîb al-T ahdhîb (Beirut: Dâr al-Kutub al-'Ilmiyyah, 1987), the same author, Lisân al-M izân (Beirut: Dâr al-Kutub al-'Ilmiyah, 1416/ 1996).

23Mahmud al-Tahhan, T aysîr M ustalah al- $\underline{H}$ adîts (Beirut: Dâr al-Qur'ân al-Karîm, 1979), hIm. 16

24 al-Khatib, U sûl al- $\underline{H}$ adîts, hlm. 32.
} 
intelligence quality, and highly established 'adalah (justice); [2] Every hadîts which records an accident with many people should be transformed as what be from many reporters. ${ }^{25}$ [3] Every hadîts should free from any verbatim destroys its validity whether that is 'illat26 or shadhdh 27 on it that is known through a deep research and investigation.

Basically, the object of matn study deals with two aspects, namely the form of hadîts text and its contents. The critique from the perspective of matn deals with text or the meaning of its contains which indicates that it doesn't involve in telling lies to the Prophet's speaking or his doing. ${ }^{28}$ Despite of sanad criticism, the application of matn critique is more difficult because the sanad appraisal depends on the five criteria of hadîts sahih. Therefore, to know the validity and authenticity of the matn of hadîts, according to Ibn al-Qayyim alJawziyyah (d. 751./ 1350), one should have the following qualifications: [1] understanding the biography of the Prophet, [2] under-standing the teaching of the Prophet, [3] understanding every commandment or prohibition of the Prophet, [4] understanding everything loved or hated by the Prophet, and [5] understanding every sharia thought by the Prophet as if he were living with him for along time like his companions.29 According to M. Syuhudi Ismail, someone who wants to be a critic of hadits matn ought to have the following qualifications: [1] having connoisseur in hadîts discipline, [2] having deep and wide knowledge about Islamic teachings, [3] having

25M uhammad Zubayr Siddiqi, "The Sciences and Critique of Hadith", in P.K. Koya (ed.), H adîts and Sunnah: Ideals and Realities (Kuala Lumpur: Islamic Book Trust, 1996 M.), hlm. 95

$26^{\prime} \mid l$ at (defective) hadîts is one which appears to be sound, but thorough research reveals a disparaging factor. Such factors can be: [1] declaring a hadîts musn ad when it is in fact mursal, or marfu' when it is in fact maw quf; [2] showing a reporter to narrate from his syaikh when in fact he did not meet the latter; or attributing a hadits to one Companion when it in fact comes through another.

${ }^{27} \mathrm{~A}$ syadhdh (irregular) hadîts is one which is reported by a trustworthy person but goes against the narration of a person more reliablethan him. It does not includea hadîts which is unique in its contents and is not narrated by someone else.

${ }^{2} 8^{\prime} U$ mar ibn $\underline{H}$ asan 'Utsmân Fallatah, al-Wad'u fî al- $\underline{H}$ adîts, vol I (Beirut: Muassasah Manâhil al-'Irfân, 1981 M/ 1401 H.), hlm. 300

29lbn al-Qayyim al-Jawziyah, al-M anâr al-M unîf fî al-Shahîh wa al-D a'îf (Beirut: Dâr alKutub al-'Ilmiyah, 1988.), hlm. 37 
been undertaken a seriously and deeply analysis, [4] having clever thinking, and [5] having high tradition of knowledge capasity. 30

Due to the above qualifications in addition to the knowledge of hadîts matn critique principles, a ciritic (naqid al-ruwah) can analyze the validity and accuracy of hadîts texts (matn). Generally speaking, according to Shalah ibn A hmad al-Dîn al-A dabi, the principles for the criticism of the texts of the traditions are as follows: [1] The hadîts doesn't contradict with the Qur'ân, [2] It doesn't oppose to the valid hadîts, [3] It corresponds to the shirah nabawiyyah, [4] It doesn't disagree with the reason, [5] It doesn't contradict with the senses, [6] It doesn't oppose to the history, [7] The hadîts indicates the saying of the Prophet, [8] It does not contain some indecisive, [9] It does not enclose meaningless texts, [10] The hadîts is not more likely the words of khalaf scholars.31

According to Muhammad Zubayr Shiddiqî, hadîts autenticity can be known through the aplication of matn critique standards, namely: [1] A hadîts should not contradict with other hadîts in the same case, acknowledged as an authentic by other competent narrators. It also should not be contrary to thetext of the Qur'an or the accepted basic principles of Islamic teaching [2] It doesn't oppose to the reason, law of nature, and human experiences. [3] The hadîts which explain highly and unproportionally rewards to a good doing or heavy and unproportionally punishments to an ordinary mistake also should be rejected. [4] The hadîts which contain extraordinary values of the Qur'anic chapters should not be accepted in general. [5] The hadîts that express positiveness and greatness of certain person, tribe or place should be rejected. [6] It is also not accepted the hadîts containing prediction of any accident in the future. [7] It is also should be rejected the hadîts of Prophet expressions (speakings, doings, or agreements) that can be prohibition of his prophetic position or every expressions that are not relevant with him. 32

\section{Hadîts Probativeness}

30M. Syuhudi Ismail, M etodologi Penelitian H adis N abi (Jakarta: Bulan Bintang, 1992 M.), hlm. 130

31Shalâh al-Dîn ibn Ahmad al-A dabi, $M$ anhaj $N$ aqd al-M atn 'Ind 'U lamâ' al- $\underline{-}$ adîts alN abawî (Beirut: Dâr al-A flaq al-Jadidah, 1983), hlm. 197-288

32 Siddiqi, "The Sciences", hlm. 96 
Through the principles of hadîts criticism, we can decide the validity of hadîts and than differ between the true (valid) and the false ones. We use a valid hadîts (al-hadîts al-shahîh) as proof for either doctrine or legal rulings. At least, we need two conditions for this: Firstly, establishment of the principle that the hadîts is one of the proofs and foundations of legislation (tasyri '). Secondly, establishment that such a hadîts actually issued from the Prophet -- Allâh bless and greet him -- through a reliable narrative chain. This condition does not apply to the Prophet companions who actually heard him say it. For the foundation of Islam is the Qur'ân, which cannot be described as Allâh's word when one unconditionally rejects the probativeness of the hadîts since the fact that the Qur'an is Allâh's word was not established by other than the Prophet's -- Allâh bless and greet him -explicit statement that this was Allâh's Word and His Book. That statement is obviously part of the hadîts. Therefore, to say that the hadîts is no proof is no different than a denial of an integral part of the Islamic religion and an attempt to undermine the basis of the religion. There are two types of hadîts that are the proofs and foundations of legislation (tasyrî'). The first is the consensus transmitted from the masses to the masses. This is one of the proofs that leave no excusefor denial and there is no disagreement concerning them. Whoever rejects this consensus has rejected one of Allâh's textual stipulations and committed apostasy. The second type of hadîts consists in the reports of established, trustworthy lone narrators with uninterrupted chains. The congregation of the ulama have said that this second type makes practice obligatory. Some of them said that it makes both knowledge and practice obligatory. Consequently, while the hadits as the proofs and foundations of Islamic legislation, every muslim should eccept it and practice everything thought and no one is allowed to deny the probativeness of every valid (shahîh) hadîts, moreover the mutawâtir ones. The probativeness of the last is the same with that of the Qur'an.

\section{Conclusion}

It is obviously understood that there are some corelations between hadîts criticism with its validity and its probativeness. $\underline{H}$ adîts criticism is usually undertaken to differenciate between the valid, the weak, and the false ones. To know the validity and accuracy of hadîts, one should master and involve himself in the conditions of becoming 
a good and profesional critic. So that, all of his critique argumentations will be held and used as the proof of hadîts validity. In other words, the validity and accuracy of hadîts not only depends on the hadîts itself but through historical investigation and methodological approach, the personal capasity and intelectual quality of it's narrators have siginficance role on wether its contents could be accepted or not. The porpuse of hadîts research and analitical points of view is not only to investigate and know its validity and accuracy as well as the profesionalism of the narrators, but for practical use is also to accommodate the usefullness as the second sources of Islam. In this case, it is absolutely needed to understand hadîts probativeness by searching its validity and authenticity.

\section{References:}

'A sqalani, Ahmad ibn Hajar al-. Lisân al-M izân. Beirut: Dâr al-Kutub al-'Ilmiyah, 1416/ 1996

-------. N uzhah al-N azhâr Syarh N ukhbah al-Fikâr. Semarang: Maktabah al-Munawwar, 1986

------. Tahdhîb al-Tahdhîb. Beirut: Dâr al-Kutub al-'Ilmiyah, 1987

'Itr, Nur al-Dîn. M anhaj al-Naqd fî 'U lûm al-H adîth. Damascus: Dâr alFikr, 1979

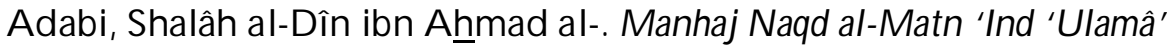
al-H adîh al-N abawi. Beirut: Dâr al-A flaq al-Jadîdah, 1983

Azami, M. M. "Studies in $\underline{H}$ adîts Methodology and Literature." Quoted in Sunnah and Hadîts, at: http:/ / www.usc.edu/ dept/ MSA.

Burton, John. An Introduction to the $\underline{H}$ adîts. Edinburgh: Edinburgh University Press, 1985

Dhahabi, al-. M izân al-'l'tidâl fî Naqd al-Rijâl Beirut: Dâr al-Kutub al'Ilmiyah, 1995 M.

Tadhkirah al-Huffâzh. Heiderabad: The Dairat el-Maarif elOthmaniya, 1955 
Fallatah, Umar ibn Hasan 'Utsmân. al-Wad'u fî al-Hadîth. Beirut: Muassasah Manâhil al-'Irfan, 1981/ 1401

Ismail, M. Syhudi. M etodologi Penelitian Hadis Nabi. Jakarta: Bulan Bintang, $1992 \mathrm{M}$.

Jawziyah, Ibn al-Qayyim al-. al-M anâr al-M unîf fî al-Sahîh wa al-D a'îf. Beirut: Dâr al-Kutub al-'Ilmiyah, 1988.

Khatib, Muhammad 'Ajjaj al-. al-Sunnah qabl al-Tadwin. Beirut: Dâr alFikr, 1971

--------. U shûl al-Hadîth 'Ulûmu wa M ustalahuh. Beirut: Dâr al-Fikr, 1989

Laknawi, Muhammad 'A bd al-Hayy al-. al-Ajwibah al-Fâdilah li al-Asilah al-'A sharah al-Kâmilah. Beirut: Maktaba al-Mathbu'at alIslamiyah, 1993 . al-Raf'u wa al-Takmil fî al-Jarh wa al-Ta'dîl. Halb: Maktab alMatbu'ah al-Islâmiyah, 1985

Lane, E.W. A rabic English Lexicon. Edinburgh: 1967

Longman, Dictionary of Contemporary English. Oxford: Oxford University Press, 1988

Qari, Ali ibn Sulthân al-Harawi al-. Sharh N ukhbah al-Fikâr. Beirut: Dâr al-Kutub al-'Ilmiyah, 1978

Rahman, Fazlur. "The Living Sunnah and al-Sunnah wa al-Jama'ah", in P. K. Hoya (ed.), $\underline{H}$ adîts and Sunnah: Ideals and Realities. Kuala Lumpur: Islamic Boook Trust, 1996

Razi, Abu Hatim al-. Kitâb al-Jarh wa al-Ta'dîl. Heiderabad: Majlis Dairah al-Ma'arif, 1952

Shalih, Subhi al-. 'U Iûm al-H adîth wa M ustalahuh. Beirût: Dâr al-'Ilm li al-Malayin, 1988

Shalâh, Abu 'Amr 'Utsman ibn 'Abd al-Rahman ibn al-. 'Ulûm al$\mathrm{H}$ adîth. al-Medinah al-Munawwarah: al-Maktabah al-'Ilmiyah, 1972 
Siba'i, Musthafâ al-. al-Sunnah wa M akânatuhâ fî al-Tasyrî' al-Islâmî. Beirut: al-M aktab al-Islâmi, 1985

Siddiqi, Muhammad Zubayr. The Sciences and Critique of $\underline{H}$ adîts, in P.K. Koya (ed.), Hadîts and Sunnah: Ideals and Realities. Kuala Lumpur: Islamic Book Trust, 1996

Subki, Tâj al-Dîn 'Abd al-Wahhab ibn 'Alî ibn al-. al-Q â'idah fî al-Jarh wa al-Ta'dîl wa al-Qâ'idah fî al-M ua'arrikhîn. al-Qâhirah: Maktab al-Matba'ah al-Islamiyah, 1984

Tahhan, Mahmud al-. Taysîr M usthalah al-H adîth, Beirut, Dâr al-Qur'ân al-Karîm, 1979

Wehr, Hans. A Dictionary of M odern Written A rabic. London: George Allen \& Unwin Ltd., 1970

Zahw, Muhammad Muhammad Abû. al-H adîth wa al-M uhadditsûn, Beirut: Dâr al-Kutub al-'Arabi, 1984 